Columbia Law School

Scholarship Archive

\title{
On the Difficulties of Generalization - PCAOB in the Footsteps of Myers, Humphrey's Executor, Morrison and Freytag
}

Peter L. Strauss

Columbia Law School, strauss@law.columbia.edu

Follow this and additional works at: https://scholarship.law.columbia.edu/faculty_scholarship

Part of the Administrative Law Commons, Constitutional Law Commons, and the President/Executive Department Commons

\section{Recommended Citation}

Peter L. Strauss, On the Difficulties of Generalization - PCAOB in the Footsteps of Myers, Humphrey's Executor, Morrison and Freytag, 32 CARDozo L. REV. 2255 (2011).

Available at: https://scholarship.law.columbia.edu/faculty_scholarship/1658

This Article is brought to you for free and open access by the Faculty Publications at Scholarship Archive. It has been accepted for inclusion in Faculty Scholarship by an authorized administrator of Scholarship Archive. For more information, please contact scholarshiparchive@law.columbia.edu, rwitt@law.columbia.edu. 


\title{
ON THE DIFFICULTIES OF GENERALIZATION- $P C A O B$ IN THE FOOTSTEPS OF MYERS, HUMPHREY'S EXECUTOR, MORRISON, AND FREYTAG
}

\author{
Peter L. Strauss*

\section{INTRODUCTION}

In considering what to write for this welcome occasion, I was struck by a certain resonance among Paul's scholarship-at least that of which I was first aware, and which I have often used to impress on students the problems of due process analysis - the important post he now holds, and a story our joint mentor, Walter Gellhorn, liked to tell on himself. In the wake of the Supreme Court's paradigm-shifting opinion in Goldberg v. Kelly, with its confident pronouncement of eight procedural elements that, it reasoned, minimal due process must always require of administrative procedures, Paul made a careful study of fortytwo different federal programs and the procedures they set for determining with finality (not as a preliminary matter as in Goldberg) the individual claims that might be involved in them. He found a pattern of enormous variety, with no more than three of Goldberg's eight minima provided in the majority of them, and all eight provided by none. Today, it seems inevitable that variety, not generalizationthe accommodation of procedural elements to the needs of particular federal programs for efficiency, accuracy, and fairness-will be a major theme of Paul's work as Chair of the Administrative Conference.

The Gellhorn story concerned his work as executive director of the committee that would eventually produce the federal Administrative Procedure Act. The monumental study of federal agency procedures he had directed, ${ }^{1}$ still regarded by many as the best empirical account of federal agency procedures ever produced, had revealed the enormous variety of approaches different agencies took in implementing their programs, to all of which efficiency, accuracy, and fairness were important. He took from this, and brought to the committee, the

* Betts Professor of Law, Columbia Law School. Thanks to Natalie Orpett, '12 and Bahrad Sokhansanj, '11, for imaginative and helpful research assistance. Any errors are my own.

1 ATTORney Gen.'s COMM. ON ADMIN. Procedure, FInAl RePORT, S. DoC. No. 77-8 (1st Sess. 1941). 
conclusion that generalizing about proper procedure (as the committee earnestly wished to do) was a hazardous undertaking. Dean Atcheson, one member, asked him in frustration, "is there not a single general principle that we can identify, that is universally observed, or ought to be observed, in all these programs?" "Well," Gellhorn responded, "perhaps advance public notice of the proceeding." And then he immediately had to demur. In banking regulation, that would be the end of the enterprise.

This all came to mind as I was reading the Supreme Court's decision in Free Enterprise Foundation v. Public Company Accounting Oversight Board ${ }^{2}$ on the very last day of its October Term 2009 last June, a decision that seemed to me torn between general principle and particularity-just as had been an earlier decision that, in some respects, it both repudiated and modeled, Freytag v. Commissioner. ${ }^{3}$ Indeed, the same problems live in two earlier cases that are staples of the administrative law and separation of powers repertoire, Myers v. United States $^{4}$ and Humphrey's Executor v. United States. ${ }^{5}$ The Supreme Court has a long history of reaching sensible results in its assessments of congressional choices about the structures of government, while having the deuce of a time explaining them. It has taken later developments to pick up the pieces. Its decision in Free Enterprise Foundation is only the most recent exhibit in this right-minded but inelegantly reasoned chain of opinions. This seemed a good occasion to reflect on the difficulties of generalization, the importance of attention to detail in this most real of all possible worlds, that Paul's work so well reflects.

\section{What (Little) The Constitution Says About the STRUCTURES OF GOVERNMENT}

The text of the United States Constitution is remarkably silent on the question of how American government should be organized. It creates and empowers a bicameral legislature, Congress, in its first Article; an elected chief executive, the President, in its second; and requires the creation of a Supreme Court, whose Justices effectively serve for as long as they choose once appointed, in its third. Everything else-including defining the size of the Supreme Court, its sitting periods, much of its appellate jurisdiction, the conditions under which it is to be exercised, and the possible responsibilities of the Justices to sit

\footnotetext{
2130 S. Ct. $3138(2010)$.

3501 U.S. 868 (1991).

4272 U.S. 52 (1926).

5 295 U.S. 602 (1935).
} 
on such inferior courts as Congress might choose to create-was left to Congress. The Constitution quite deliberately omitted to define the structures of America's executive government, even while anticipating in its text that there would be executive "Departments" with "Duties" Congress would assign, and that, as they exercised those duties, those departments would have a responsibility to interact with the President, who was made generally responsible for their faithful execution of the laws. ${ }^{6}$ Rather, it gave Congress the authority to legislate in any way "necessary and proper" to support its substantive legislative choices ${ }^{7}$ and, transparently, this, of necessity, included the authority to establish governmental organs to that end. From the very beginning, Congress has been creating governmental bodies, not in cookie-cutter fashion, but in a rainbow of patterns each responding to the anticipated needs of the particular regime being created. ${ }^{8}$

Separation of power questions arise because, with equal unequivocality, the Constitution vests "the executive power" in a single individual, our elected President. ${ }^{9}$ What are his necessary relationships to the executive bodies Congress creates, and to the officials who work there? To what if any extent may Congress share in those relationships? The Constitution's text says very little about this. It is for him to nominate, and the Senate to confirm, all the government's "officers," unless and to the extent Congress chooses to vest the authority to appoint "inferior officers" in him, in the "Heads of [the] Departments [it creates]," or in the courts. ${ }^{10}$ It would seem that one cannot be an "inferior officer" without having a superior between oneself and the President, with the result that senatorial confirmation is required for the heads of departments. ${ }^{11}$ With the need for confirmation come both one

6 U.S. CONST. art. II.

7 Id. art. I, § 8.

8 See, e.g., Laurence Lessig \& Cass Sunstein, The President and the Administration, 94 COLUM. L. REV. 1 (1994).

9 U.S. CONST. art. II.

10 Id. art. II, $\$ 2$, cl. 2.

11 This proposition seems quite obvious, but on one prominent occasion on which the Court might have stated it, in considering the constitutionality of the Federal Election Commission, it oddly sidestepped the question:

If "all persons who can be said to hold an office under the government about to be established under the Constitution were intended to be included within one or the other of these modes of appointment," United States v. Germaine, supra, it is difficult to see how the members of the Commission may escape inclusion. If a Postmaster first class, Myers v. United States, 272 U.S. 52 (1926), and the clerk of a district court, Ex parte Hennen, 13 Pet. 230 (1839), are inferior officers of the United States within the meaning of the Appointments Clause, as they are, surely the Commissioners before us are at the very least such "inferior Officers" within the meaning of that Clause... . "Officers of the United States" does not include all employees of the United States, but there is no claim made that the Commissioners are employees of the United States rather than officers. Employees are lesser functionaries subordinate to officers of the United States, see Auffmordt v. Hedden, 137 U.S. 310, 327 (1890); United States v. 
kind of relationship to Congress - the possibility that promises will have been made to powerful politicians other than the President during the confirmation process-and the political reality that the President cannot be assured that any choice of officer he might prefer will be accepted. The Constitution contains not a word about the President's power to remove any of these officers, once appointed-merely that if Congress wishes to remove an officer, its route is the formal procedure of impeachment. ${ }^{12}$ And perhaps the easiest reading of its text is that it establishes a consultative rather than a commanding relationship with government officers outside the nation's military. It makes the President "Commander in Chief" of the country's armed forces; as to those at the head of the departments Congress may have created to conduct the affairs of domestic government, however, it says only that he may require their "opinion in writing" about how they will exercise any duties Congress may have assigned them. ${ }^{13}$ And, of course, those assignments of duty are a part of the laws whose faithful execution the President is obliged to assure. ${ }^{14}$

Against this paucity of text one may pose theories about the necessary elements of the separation of powers-what it means to have vested "the executive power" (as if one knew exactly what that was) in one individual; how it may be distinguished from "the legislative power" that is vested in Congress; and what principles are necessary to assure that the two are not merged. And one may witness that Congress, acting in response to perceived public needs (and perhaps also in the inappropriate pursuit of its own hegemony), has created an enormous variety of institutions that one might think suited to the particular requirements of their particular responsibilities. Reconciling the political theories that might be developed out of the Constitution's history and text with these particular, practical accommodations has often proved hazardous.

Germaine, supra, whereas the Commissioners, appointed for a statutory term, are not subject to the control or direction of any other executive, judicial, or legislative authority.

Buckley v. Valeo, 424 U.S. 1, 126 n.162 (emphasis added). The issue appears to have been settled by the formula subsequently adopted by the Court for identifying "inferior officers" in Edmond v. United States:

[I]n the context of a clause designed to preserve political accountability relative to important government assignments, we think it evident that "inferior officers" are officers whose work is directed and supervised at some level by others who were appointed by presidential nomination with the advice and consent of the Senate.

520 U.S. 651,663 (1997).

12 U.S. CONST. art. II, $\$ 4$.

13 Id. $\& 2$, cl. 1.

14 Id. $\S 3$. 


\section{WHAT WAS “THE DECISION OF 1789"?}

The question of who controls the tenure of government officials, once appointed, divided the Congress and the nation from the start. The first Congress, creating the new government, established some offices that were clearly at a remove from the presidency-those charged with creating the budget were virtually its own - and debated and narrowly decided that the President should (ordinarily) have a right of removal. ${ }^{15}$ But was it that the President must be given an unfettered right to remove any official who displeased him, or rather that the Senate should not participate in the decision - even if it did participate in the decision to confirm an appointment? In the debates, much was said about the President's necessary relationship with the officers serving under him, and his need to change if he lost faith in the incumbent. Yet the decision of 1789 , as such, was not to state explicitly his authority to remove, but rather to reject proposals that would have provided for senatorial participation in removal. His own removal authority remained unstated, implicit. And early Congresses did not hesitate to create federal offices whose incumbents were to serve for a term, at least implicitly protected from casual removal during that period. ${ }^{16}$

Later, Congress changed its mind on the issue of its own participation. When Andrew Johnson became President upon Abraham Lincoln's assassination, the Tenure in Office Act ${ }^{17}$ required Senate participation in removals from Cabinet positions, to protect the Lincoln cabinet from dismemberment by the new President. Clearly this was both an expression of distrust in the new President, and an effort to involve the Congress in executive branch business. When President Johnson then purported to remove Lincoln's Secretary of War Edward Stanton from office, articles of impeachment were voted by the House of Representatives and, in the Senate, impeachment came within one vote of success.

Subsequently, a more innocent statute provided the same protection to city postmasters. The requirement of Senate acquiescence in their removal is easily understood as a political gesture toward the Senators of the relevant state, who would have had a good deal to do with the appointment in the first place. President Wilson acted to

15 See, e.g., Lessig \& Sunstein, supra note 8.

16 Consider, for example, William Marbury, whose five-year commission to be a minor judicial official for the District of Columbia was the matter at issue in Marbury v. Madison, 5 U.S. 137 (1803).

17 An Act Regulating the Tenure of Certain Civil Offices, ch. 154, 14 Stat. 430 (1867) (repealed 1887). 
remove the Postmaster of Portland, Oregon without consulting the Senate, and Myers v.United States ${ }^{18}$ was the result.

The case had to be argued twice. When finally decided, it was by the narrowest of margins. The majority concluded that Postmaster Myers had been validly removed from office, because the statute constraining the President's actions was unconstitutional. But why? Chief Justice (and former President) William Howard Taft wrote the majority opinion and--perhaps not surprisingly given the perspective he might have brought to the case from his prior position ${ }^{19}$-his very lengthy opinion is full of emphatic assertions of the necessary prerogatives of the President as chief executive. Perhaps not for officials to whom were committed adjudicatory tasks, but certainly for those performing strictly executive functions (like a city postmaster), he wrote, the President's removal power must be unhindered. The "Decision of 1789," reflecting the constitutional understanding of the Framers, he argued, established as much. These expressions are invoked again and again by those taking the strongest view of presidential authority, and subsequent departures from them are bemoaned. ${ }^{20}$

The case is written as if, and is often said to have held that, with the exception of civil service members and officers whose role is the adjudication of contested matters, the President must have an unfettered right to remove executive officers at will. Yet the restraint it found unconstitutional was a congressional effort to require senatorial approval of the removal of the postmaster (an executive official) from office-that is to say, it required the Senate's participation in the President's executive action. Seen this way, the case gave the Court a belated and welcome chance to pronounce judgment on the Tenure in Office Act - to place limits on the capacity of Congress to participate in overseeing executive action. But it was written a good deal more broadly.

If thus seen in relation to its facts, and not as the fount of a theory of sweeping theories of necessary presidential authority, the case would have had few implications for other established institutions and governmental positions. Viewed in the light of its ostensible theory, however, those implications were striking. By the time the Court decided Myers, not a few important governmental officials-for

18272 U.S. 52 (1926).

19 Cf. Robert R. Robinson, Executive Branch Experience, Supreme Court Nominees, and Increased Deference to the President in Separation of Powers Cases: Signaling, or Socialization? (May 18, 2010) (unpublished manuscript), available at http://ssm.com/abstract=1610257.

20 See, e.g., STEVEN G. CALABRESI \& CHRISTOPHER S. YOO, THE UNITARY PRESIDENT: PRESIDENTIAL POWER FROM WASHINGTON TO BUSH (2008); John C. Yoo, The Continuation of Politics by Other Means: The Original Understanding of War Powers, 84 CALIF. L. REV. 167 (1996). 
example, the Commissioners of the FTC and the Governors of the Federal Reserve-were protected from unreasoned presidential interference with their tenure in office; the civil service, whose members were also in positions of protected tenure, held jobs such as Director of the National Forest Service. These positions had no less importance in relation to the execution of the laws than that of city postmaster. If aware of these facts, the majority did not pause to consider the impact of its words on them.

After Myers, Congress did not change any statutes already on the books that the sweeping theoretical approach of its opinion threatened; but, aware of its warning, it omitted providing "for cause" protection for the tenure of new commissioners when in following years it created new independent regulatory commissions along the otherwise accustomed lines it had established with the creation, inter alia, of the FTC. It did not provide "for cause" protection, for example, for the commissioners of the Securities and Exchange Commission, fearing that - if it did-the whole of the scheme it was enacting might have been declared unconstitutional. ${ }^{21}$ Was it right not to have done so? Or should it have noticed that, however broad the opinion's language-grounded in a disputable theory about what it means to be vested with "the executive power"-Myers could be much more easily understood in terms of the limited proposition that was all the Court was required to decide on its facts: Congress may not reserve a place for itself in decisions about removal. ${ }^{22}$ And of course "for cause" removal provisions, no more than the civil service laws, did not create a role for Congress. They merely structured the President's authority within the executive branch.

\section{CAN Congress CREATE A "Headless Fourth BRANCh”?}

The constitutionality of "for cause" limitations on the President's removal authority came before the Court not a decade later, and was much more quickly and emphatically resolved. President Franklin Roosevelt found a conservative Republican Commissioner sitting on the Federal Trade Commission, and purported to remove him, not "for cause," but simply because he wanted someone more likely to agree with his policy views in that seat. Commissioner Humphrey resisted and, although he soon died, his widow's claim for his continuing salary brought the matter to the Court. It speedily and unanimously found the "for cause" restriction valid, and in Humphrey's Executor v. United

21 Free Enter. Fund v. Pub. Co. Accounting Oversight Bd., 130 S. Ct. 3138, 3183 (2010) (Breyer, J., dissenting).

22 Accord Bowsher v. Synar, 478 U.S. 714 (1986). 
States $^{23}$ found widow Humphrey entitled to her late husband's unpaid wages.

It might have explained its decision in light of Congress's undoubted authority to structure our government, casting an eye on the variety of patterns it had been following in doing so. It might have noted that here, as not in Myers, Congress had left the power of removal solely in the hands of the President, albeit somewhat constrained. And it might then have explored the full range of the President's capacities for assuring the FTC's faithful execution of the laws, in relation to its particular responsibilities. Were the FTC to be treated as a "Department" with "Duties," for example, the President would be able to require the FTC's consultation with him on its important decisions about how to exercise those duties. Nor need a "for cause" restriction interfere with his assuring that "the Laws be faithfully executed," as failures of legality would surely satisfy the restriction. Agencies like the FTC are quite distinct in this respect from, say, a Department of State or a Department of Defense. The latter exercise a kind of discretion on the President's behalf that makes them, as Chief Justice Marshall wrote in Marbury v. Madison, "the mere organ by whom [the President's] will is communicated. The acts of such an officer, as an officer, can never be examinable by the courts." 24

But such discretion as the FTC might possess, the Court would insist, could be tolerated only if subject to judicial controls for legality. ${ }^{25}$ "For cause" constraints on the removal of one who is, to any significant degree, "the mere organ by whom [the President's] will is communicated" would present much more difficult issues than such constraints on organs generally constrained by enforceable considerations of legality. ${ }^{26}$

But this was not the Court's analytic route. Chief Justice Hughes, writing for a unanimous Court, concluded that (with a minor exception acknowledged and trivialized in a footnote) the FTC exercised only legislative and judicial powers. Therefore, it was not a part of the executive branch. Consequently, it need have no relationship with the President. This left the Commissioners' "for cause" protection in place, but at what costs? Intellectual coherence, for one: In a government of three branches that it acknowledged must be kept separate, the Court avoided placing the FTC in the executive branch only by seeming to have put it simultaneously into both the legislative and judicial branches. Or perhaps it jumped back and forth between the two, depending what it was doing that day? This difficulty commentators,

23295 U.S. 602 (1935).

245 U.S. 137, 166 (1803) (emphasis added).

25 See A.L.A. Schechter Poultry Corp. v. United States, 295 U.S. 495 (1935).

26 Cf. Bowsher, 478 U.S. at 763-64 (White, J., dissenting). 
and perhaps for a while the Court, avoided by treating the independent regulatory commissions as elements of a headless fourth branch. But of course that characterization only emphasizes the problems involved in connecting their existence with the Constitution. Now Congress might believe it could create agencies to administer the laws that were outside the President's reach-and the commissioners of those agencies and others might come to share those disturbing beliefs. ${ }^{27}$

A decade or so later, when it enacted the Federal Administrative Procedure Act, Congress paid no attention whatever to the possibility that the rulemaking, adjudicating, and policy-implementing procedures for which it was providing would be exercised both by "executive branch agencies" like the Bureau of Land Management nestled in the Department of the Interior and "independent regulatory commissions" like the SEC. Without a statutory word suggesting discrimination among them, all were charged with implementing their particular responsibilities in accordance with the procedures established by the act. If rulemaking or adjudication was an executive branch activity in the hands of the BLM when it was implementing the nation's land use laws, what was it when the SEC was implementing securities regulation regimes? And if the President was required to see to the BLM's faithful execution of the laws placed in its care, what excused him from the same responsibility vis-à-vis the SEC?

27 Three examples from the author's personal experience:

During the time he was General Counsel of the Nuclear Regulatory Commission (and, he believes, ever since), the President's Office of Management and Budget quite properly sought the Commission's views on legislative proposals that might affect it (one of the variety of ways in which the President treated the Commission as within his ken, if somewhat remotely so). One such, not so long after Watergate, proposed to regularize claims of executive privilege by requiring the President himself to make the claim on behalf of the executive agency whose cooperation was being sought. As written, the bill would have prevented the President from claiming executive privilege for materials held by the Commission. As much extremely sensitive material about nuclear plant security, weapons, etc., was in the Commission's files, it responded suggesting a change in the legislation to embrace the Commission (and any other independent regulatory commission that might hold such materials in its files). An attorney in the Department of Justice's Office of Legal Counsel responded that this could not be done, as the NRC was not a part of the executive branch.

Shortly after returning to the academy, the author had a conversation with a friend and fellow academic who had been a Commissioner of the Securities and Exchange Commission. He advanced his view, explored in Peter L. Strauss, The Place of Agencies in Government: Separation of Powers and the Fourth Branch, 84 CoLUM. L. REV. 573 (1984), that the President had important oversight relations with independent regulatory commissions, relations that the commissions had an obligation to acknowledge. The former Commissioner recoiled in horror: "But the SEC is an independent regulatory commission! The President has no business asking anything of us!"

More recently, in another conversation with another friend and former academic who had taken an important directorship at the FTC, discussing how the FTC and the Department of Justice resolved antitrust policy issues, essentially the same conversation recurred. He could not imagine that the President had any legitimate role. 
These confusions would have been readily enough avoided if the Humphrey's Executor Court had seen the question presented to have been whether Congress can give "for cause" removal protection to some officials of the executive branch who are appointed by advice and consent. 28 The power to remove "for cause" is not an empty one. Nor need it be the President's only possible authority in relation to those enjoying its protection-for example, again, there is his constitutional right to demand opinions in writing of the heads of departments before they exercise the duties Congress has legislated for them. This right is senseless without a corresponding obligation, at the least, to hear the President out before acting, to have a conversation. Whether these and other relations the President may enjoy with them satisfy the necessities of "the executive power" the Constitution vests in the President is a question that could be answered case by case. It was, perhaps, the Myers formulation, and not an appreciation for that case's limited context, that kept the Court from this path, perhaps more difficult but also more honest, and one more readily reconciled with the Constitution's basic structure.

\section{Who ARE THE HEADS OF DEPARTMENTS IN WHOM CONGRESS MAY CONSTITUTIONALly Vest THE POWER TO APPOINT "INFERIOR OFFICERS"?}

The Constitution explicitly empowers Congress to create exceptions to the default provision for the appointment of officers of the United States, that appointments are to be made by the President with the advice and consent of the Senate. For "inferior officers" it may empower the President alone, the heads of departments, or the courts to make such appointments directly. ${ }^{29}$ Who is an "inferior officer" raises its own set of questions of definition. Clearly enough, the set of "inferior officers" must be bounded on both sides. Some positions - an office assistant, say-simply do not have "officer" importance; "employee" is more like it. Others, for whom no authority intercedes between them and the President, are too important to be regarded as

28 For persons appointed by the President directly, by Heads of Departments, or by the courts under statutes enacted pursuant to the permission given Congress by Article II, this question had already been answered in the affirmative. Congress's power to create exceptions to the "advice and consent" route carried with it the power to specify the terms on which the positions would be held. As has already been suggested, see supra text accompanying note 11 , the nature of the discretion to be exercised by an appointee might be thought to limit Congress's power to confer "for cause" protections on principal officers.

29 U.S. CONST. art. II, $§ 2$, cl. 2. 
"inferior;" it would seem that Senate confirmation of these persons must inevitably be required. ${ }^{30}$

Half a century after Humphrey's Executor, the upper limit found an important test in Morrison $v$. Olson, ${ }^{31}$ upholding the Office of Independent Counsel. In the wake of Watergate, Congress had established a legal regime in which the Attorney General's grounded suspicions that a high executive official, even the President, had committed crime would lead to appointment of "Independent Counsel" by a special judicial panel; she was then to investigate and perhaps prosecute any crime, under only limited supervision by the Attorney General. In an opinion written by Chief Justice Rehnquist, a conservative Justice who had once served as head of the Office of Legal Counsel (the office chiefly responsible for the Department of Justice's legal advice to the President), eight Justices found this regime to be constitutional. No one could or did pretend that the independent counsel performed no significant executive function; the majority, rather, concluded that the possibility of the Attorney General's removing him "for cause," and his obligation ordinarily to be governed by general Department of Justice policies, made him an "inferior officer" with a constitutionally sufficient relationship to the President. Thus, it limited the sweep of Myers's language, noting the limited question that case had been required to decide and adopting the totalityof-the-circumstances analysis so missing from Humphrey's Executor. Justice Scalia, as a lone dissenter, violently disagreed both with the Court's theoretical approach to the "inferior office" question and with its application in the particular circumstances of this office.

In the wake of Ken Starr's years as Independent Counsel in pursuit of President Clinton, most might say that the verdict of history supports Justice Scalia's assessment of the majority's application of its totalityof-the-circumstances approach to the particular case of Independent Counsel. The statute was permitted to lapse, and seems unlikely ever to be reenacted. But it was Justice Scalia who wrote for the Court in Edmond v. United States, ${ }^{32}$ which permitted the Secretary of Transportation to appoint civilian members of the Coast Guard's Court of Criminal Appeals. Now, with only Justice Souter writing separately, he recast the test for the upper limits of "inferior officer" in a way that can be seen to embody just such an approach:

[I]n the context of a clause designed to preserve political accountability relative to important government assignments, we think it evident that "inferior officers" are officers whose work is directed and supervised at some level by others who were appointed 
by presidential nomination with the advice and consent of the Senate. ${ }^{33}$

Edmond not only accepts the fluid formulation of the Morrison majority; it also reacts to an earlier, closely divided opinion of the Court that again suggested the difficulty of relying on high theory to decide the application of our eighteenth century Constitution to governmental structures of the current day. In 1991, Freytag v. Commissioner ${ }^{34}$ had appeared to raise a significant question whether independent regulatory commissions (or their Chairs) could constitutionally be regarded as being among the "Heads of Departments" Congress could constitutionally authorize to appoint "inferior officers." Recall that under the Constitution, all "officers" must be appointed by the President with the advice and consent of the Senate, unless Congress has authorized direct appointment by the President, Heads of Departments, or the courts. Congress had habitually authorized commissions or commission chairs to appoint the commissions' general counsel, the heads of their important bureaus, and others with high levels of responsibility for implementing their programs.

Freytag itself had put before the Court the appointment of a relatively minor quasi-judicial official of the Tax Court (a body established by Congress under Article I and not an Article III court), who because he exercised decisional authority was nonetheless an "inferior officer." Writing for a bare majority, Justice Blackmun reasoned from the Framers' original understandings and purposes that the "Heads of Departments" Congress could invest with appointment authority must be narrowly understood. Given the Framers' apprehensions about "the most insidious and powerful weapon of eighteenth century despotism," they must be the heads of Cabinet-level departments, "limited in number and easily identified. Their heads are subject to political oversight and share the President's accountability to the people." 35 What, then, about people like the General Counsel of the Nuclear Regulatory Commission (a position to which I had earlier been appointed by that Commission)? The General Counsel, essentially independent in his responsibility for litigating on behalf of the Commission and giving commissioners legal advice, is clearly an "inferior officer," and just as clearly the NRC is not one of those Cabinet-level departments, "limited in number and easily identified."

The Court declined to reconcile its reasoning with the realities of contemporary government. Having forcefully stated his reasoning (which the official in question in Freytag escaped because the majority somehow associated his appointment with the "Courts of Law"), Justice

$33 \mathrm{Id}$. at 663.

34501 U.S. 868 (1991).

$35 \mathrm{Id}$. at 886 . 
Blackmun then appended to his opinion a footnote as curious and muddling as had been the Court's decades-earlier denial in Humphrey's Executor that the FTC exercised executive branch functions ${ }^{36}$ : "We do not address here any question involving an appointment of an inferior officer by the head of one of the principal agencies, such as the Federal Trade Commission, the Securities and Exchange Commission ... and the Federal Reserve Bank of St. Louis." 37 If one believes this footnote, what has become of the text's history-grounded insistence on the necessity of limitations on number, and on "Heads of Departments" who share the President's accountability to the people?

Justice Scalia (who has been heard by your author to describe Freytag as the single worst opinion of his incumbency) concurred for four, rejecting the majority's "Courts of Law" rationale, and simply taking the constitutionality of the FTC in particular, and the great variety of federal agencies in general, to have become established. History had to be taken to trump originalism in this case; given all the congressional water that had been permitted to flow under the bridge, return to the text would simply be too disruptive.

Although "inferior officer" issues became somewhat clearer with Edmond v. United States, ${ }^{38}$ one may note a certain tension in its formulation. Freytag's originalist theme, and so perhaps also its apparent limits on congressional delegation of the appointment power to department heads, is preserved by the phrase: "in the context of a clause designed to preserve political accountability relative to important government assignments." 39 On the other hand, that theme does not so clearly live in the words that follow: "directed and supervised at some level by others who were appointed by presidential nomination with the advice and consent of the Senate." 40 In any event, Edmond did not directly repudiate Freytag's impeccable originalist reasoning, or the surprising results the theory attributed by the majority to the Framers might entail. Freytag's muddling if reassuring footnote, an inexplicable repudiation of the text, remained.

\footnotetext{
36 See supra Part III.

37501 U.S. at 887 n.4.

38520 U.S. 651 (1997); see also supra note 11 and accompanying text.

39 Id. at 663 .

40 Id.
} 


\section{CAN CONGRESS PROTECT AN INFERIOR OfFICER FROM REMOVAL FROM OFFICE WITHOUT "CAUSE," IF HER SUPERIOR IS SIMILARLY PROTECTED?}

This brings us, finally, to Free Enterprise Fund v. Public Company Accounting Oversight Board, ${ }^{41}$ argued early in December 2009 but not decided, by the narrowest of margins, until June 28, 2010, the final day of the Supreme Court's October Term 2009. The case questioned the constitutionality of a particular form of government entity a nearunanimous Congress had created, with strong presidential support, to oversee the business of public company accounting. Pre-crash scandals such as Enron and World-Com had revealed the inadequacies of the accountancy profession's efforts at self-regulation, and now Congress acted to replace those deficient efforts with effective external regulation. This was to be accomplished by a new multi-member body, the Public Company Accounting Oversight Board. As accountancy principles had particular importance for the auditing of public companies whose shares were subject to the regulation of the Securities and Exchange Commission, one of America's "independent regulatory commissions," Congress provided that its members were to be appointed by the SEC and act under its careful and unusually extensive oversight. They could be removed from office only by the SEC and only "for cause," on limited grounds, and following formal procedures.

Congress's choices in creating the PCAOB may suggest both the wide variety of government institutions it has established, and the difficulties involved in measuring them against the Constitution's limited provisions. Neither any party nor any Justice doubted that the PCAOB must be considered a "government entity" in assessing any constitutional constraints imposed by separation of powers considerations. Yet in many respects-and not only those that excited this litigation-it is an odd duck. Its five members each earn a salary considerably higher than is paid to any person we might usually think a government official, including our President. ${ }^{42}$ Its employees are free of the salary restrictions and other characteristics of the civil service system. The expense of maintaining them, and the PCAOB's program generally, is met not by the congressionally enacted appropriations our Constitution calls for to justify the spending of public moneys, but from

41130 S. Ct. $3138(2010)$

42 The PCAOB Chair's annual salary is $\$ 673,000$ and other members' salary is $\$ 547,000$, "roughly four times greater than [those of SEC Commissioners]." Brief for Petitioner at 49-50, Free Enter. Fund v. Pub. Co. Accounting Oversight Bd., 130 S. Ct. 3138 (2010) (No. 08-861), 2009 WL. 2247130. 
fees collected from both the accounting industry it is responsible to regulate and the public companies they audit, in accordance with a budget approved not by Congress but by the SEC. While the parties conceded that it was a "government entity," the PCAOB is not a "government agency." Consequently, its rulemaking and adjudicatory activities, although essentially subject to approval de novo by the SEC, are not governed by the federal Administrative Procedure Act and are not directly subject to judicial review under that act. In some or all of these respects, respects that were not prominent in the litigation, it is not alone. The Postal Service, the Federal Reserve and its member institutions, the Tennessee Valley Authority, and the Bonneville Power Authority are among the mixed-character "government entities" Congress has created over the years.

In certain respects, too, the PCAOB resembles quasi-public institutions like the stock exchanges and the National Association of Securities Dealers, that since $1938^{43}$ have regulated investment activities in the shadow of the SEC. These institutions regulate professional activities and discipline members for violations of the SEC's or the organization's rules, in the interest of promoting selfregulation, but subject to the plenary supervision of the SEC. ${ }^{44}$ Over the years, Congress has expanded this relationship 45 "to ensure that there is no gap between self-regulatory performance and regulatory need." 46 The activities of these organizations are diverse and their expertise substantial, supplying disciplinary resources the federal government could not easily afford. ${ }^{47}$ Operating under SEC review, they control their officers and budget, and adopt their own rules of discipline and practice (albeit subject to standards the SEC will enforce on its review of individual disciplinary proceedings).

Congress, then, was building on reasonably familiar models in creating the PCAOB. Yet in the interests of both closer SEC control and avoidance of self-interested self-regulation, it placed the PCAOB much more tightly under SEC control. Its budgets and the fees that support them must be approved by the Commission. The rules it

43 Maloney Act, Pub. L. No. 719, 52 Stat. 1070 (1938) (codified at 15 U.S.C. § 780-3(a) (2006)).

44 For a general consideration of this scheme, see National Ass'n of Securities Dealers, Inc. $v$. $S E C, 431$ F.3d 803 (D.C. Cir. 2005), on which this paragraph generally relies.

45 See, e.g., Securities Acts Amendments of 1975, Pub. L. No. 94-29, 89 Stat. 97 (1975).

46 S. REP. No. 94-75, at 3 (1975).

47 Some detail is supplied by a graphic display from the 2008 Annual Report of the Financial Industry Regulatory Authority (FINRA), which in 2007 displaced both the New York Stock Exchange and the National Association of Securities Dealers as the "self-regulatory organization" for their memberships. See FIN. INDUS. REGULATORY AUTH., 2008 YEAR IN REVIEW AND ANNUAL FINANCIAL REPORT: REForming Regulation to BetTER PROTECt INVESTORS (2009), available at http://www.finra.org/web/groups/corporate/@corp/@about/@ar/documents/ corporate/p1 19061.pdf. 
enforces and the penalties it imposes for violations are subject to Commission approval and displacement. Its leadership is appointed by the Commission to fixed terms of office, which can be terminated prematurely by the Commission only on a finding of "cause" on one of three specified grounds, two of which require "willful" misconduct in office. In these respects, one could say that Congress had created a new model-an independent commission within an independent commission -and it was this possibility, compounded by the role of the SEC, that fueled the constitutional controversy.

The SEC itself, as an independent regulatory commission, has only a limited relationship with the President. Its Commissioners, too, serve fixed terms and the majority's opinion is premised on the proposition that they may be removed by him only "for cause." 48 The President's capacity to oversee the policymaking of independent regulatory commissions like the SEC is, at best, untested. If Congress in creating the PCAOB made it, unlike the New York Stock Exchange, the NASD, FINRA - or for that matter the American Bar Association, lawyers' SRO - so close to the SEC as to have become a "government entity" charged with law-execution, did it place the PCAOB so far away from the presidency as to defeat our Constitution's vesting "the executive Power . . . in a President of the United States"? 49

Congress unquestionably has the legislative responsibility to create the institutions of American government. Its choices in creating the structures of government over the years have been highly varied, as particular problems appear to call for particular approaches, and they have often answered to its appreciation of the need for institutional distance from raw politics. Yet there is also the risk that they embody an impermissible preference to substitute its own supervision of "faithful execution" for the President's. Assessing that risk-protecting the President's exclusive and unconditional responsibility to oversee the faithful execution of the laws it enacts-characterizes American separation of powers jurisprudence. The disputes in the case lay in that risk assessment, and its relation to the Constitution's text and the existing, well-established framework of laws structuring the President's relationship to the bureaucracy.

When argued in the United States Court of Appeals for the District of Columbia Circuit, this question engendered passionate arguments that divided the court two to one. ${ }^{50}$ Judge Judith Rodgers, upholding the statute in every respect, detailed and relied upon the extensive controls given the SEC over PCAOB decisionmaking. In light of those

48 See infra note 61 and accompanying text.

49 U.S. CONST. art. II, $\S 1$, cl. 1.

50 Free Enter. Fund v. Pub. Co. Accounting Oversight Bd., 537 F.3d 667 (D.C. Cir. 2008), rev'd in part, 130 S. Ct. 3138 (2010). 
controls she concluded that the provision for SEC rather than presidential appointment of the Board members was proper: They were "inferior officers," and (Freytag to the contrary notwithstanding) the SEC could be regarded as a "department" for Appointments Clause purposes. As inferior officers of a properly constituted government agency, she concluded, board members could be protected from removal except "for cause." The Free Enterprise Fund, which with some conservative commentators was hoping for a return to Myers's emphatic language about necessary presidential authority, found a friend in Judge Brett Kavanaugh, dissenting. His dissenting opinion hinted at the hope that the Supreme Court, reviewing this decision, would endorse the position that the President, vested with "the executive power," must have at least that degree of authority over agency action as would permit him to remove any government official exercising executive authority for any reason, free of "for cause" restrictions. He wondered if the time had not come for the Court to reconsider its acceptance of "for cause" protection in Humphrey's Executor; or to reconsider its willingness to accept "inferior officer" status for officers with major responsibilities for law-execution, as in Morrison. One could believe that he would have preferred it if Board members must be appointed by the President with the Senate's advice and consent, and were then directly removable by him without need for "cause." In any event, he concluded, to have both of these authorities in the hands of an independent regulatory commission, already one step removed from presidential controls, was to place major responsibilities for law-execution too far from the President in whom the Constitution vested all "executive power."

The grant of certiorari in the case was taken by many to signal that a reconsideration of these precedents might indeed be pending. That the case took almost seven months for the Court to issue its opinions can be taken as a signal of its difficulty. The majority opinion was written by Chief Justice Roberts for what is conventionally regarded as the conservative wing of the Court (himself and Justices Alito, Kennedy, Scalia and Thomas), some of whom have shown considerable willingness to return to first principles in the face of prior decisions, and have been sharply critical of Humphrey's Executor in particular. ${ }^{51}$

51 Justice Scalia has expressed no great love for Humphrey's Executor, even if he has accepted that this particular horse has long since left the proverbial barn. His dissent in Morrison v. Olson, for instance, refers to Humphrey's Executor as "gutting, in six quick pages devoid of textual or historical precedent for the novel principle it set forth, [the] carefully researched and reasoned 70-page opinion" of Chief Justice Taft in Myers. Morrision v. Olson, 487 U.S. 645, 725-26 (1988) (Scalia, J., dissenting). Just last year, writing for himself and three others in $F C C$ v. Fox Television Stations, 129 S. Ct. 1800, 1817 (2009), he employed a grim simile, identifying as "the lion's kill" the "power that Congress has wrested from the unitary Executive" via the creation of independent regulatory agencies, $i d$; he recurred to Freytag in denying any "reason to 
The outcome of the case was hardly earthshaking, however. For example, drawing on the first phrase in Edmonds, petitioners strongly argued, as did some commentators, that the importance of the PCAOB's responsibilities required that its members be regarded as "principal officers" of the United States, whose appointment must, therefore, be made by presidential nomination and senatorial consent. Not a Justice found merit in that contention. They were unanimous that the SEC's considerable authority over their actions rendered them "inferior officers" within the Edmonds formulation. And, again unanimously, the appointments clause confusions resulting from Freytag's simple theory, so inadequate for the realities of contemporary government, were unceremoniously swept aside. The SEC, all nine Justice agreed, is a constitutional "department" for appointments clause purposes. Thus, Freytag notwithstanding, it could constitutionally be given the power of appointing inferior officers, including for these purposes the members of the PCAOB.

Note how this seemingly straightforward conclusion leaves at least two difficulties in relation to the constitutional text-an observation made not in criticism so much as to suggest that the grounding of this opinion, as the others discussed here, lies more securely in the particular circumstances presented to the Court than in any particular theoretical structure.

First, since the members of the PCAOB are outside what we might conventionally regard as the federal government (heads of a government "entity" but not of an "agency" for APA purposes) and since they are paid at levels unthinkable for government officials in the conventional sense, what is it that makes the members of the PCAOB "inferior officers" of the SEC? While the argument that they must be regarded as "principal officers" having to be appointed by presidential nomination and senatorial confirmation was easily rejected by all, given the SEC's tight control over their activities, is it only the parties' "government entity" concession that makes them governmental officers at all? Of

magnify the separation-of-powers dilemma posed by the Headless Fourth Branch." One may remark that with the PCAOB decision and others, there has ceased to be a "Headless Fourth Branch." The independent regulatory commissions are accepted as departments having a necessary relationship to the President, and their actions are now properly characterized as executive actions. See Strauss, supra note 27. There remains an issue about what having a "unitary Executive" means, but it is not that functions of executive government have been placed beyond presidential reach.

One is reminded of a remarkable line from Justice White's dissent in another virtually impenetrable separation of powers case, Northern Pipeline Construction Co. v. Marathon Pipe Line Co., 458 U.S. 50, 94 (1982): "Whether fortunate or unfortunate, at this point in the history of constitutional law [the question what limits may exist on Congress's ability to create adjudicative institutions to carry out federal policy that are not Article III courts] can no longer be answered by looking only to the constitutional text." On the inevitable and necessary failures of simple originalist textualism generally, see Henry Paul Monaghan's magisterial Supremacy Clause Textualism, 110 COLUM. L. REV. 731 (2010). 
course, the drafters of the Constitution did not anticipate such variety in government "entities"- the TVA or AMTRAK any more than the $\mathrm{PCAOB}$ - and issues like this, rather impossible of textual resolution, illustrate the continuing challenges of fitting an eighteenth century doctrine to modern times.

Second, in footnote eleven ${ }^{52}$ of its opinion, the majority says that while it has decided that the SEC is a "department" for the purposes of the appointments clause, it is reserving the question whether the SEC should be considered an "executive department" from the head(s) of which the President is given constitutional authority, as an explicit element of his executive power, to demand an opinion in writing about their exercise of their statutory responsibilities. Yet to reach its agreed conclusion, the Court had unanimously characterized the SEC as a department and its actions as "executive." How, then, could SEC Commissioners fall outside the obligations of the Opinions in Writing Clause? To say that Congress would prefer such a conclusion, because it likes to think of the independent regulatory commissions as in some sense its own, independent of the President but not of Congress, either returns us to the "headless fourth branch" or puts Congress in the dominant position respecting these responsibilities for law-execution. Neither proposition is acceptable, given the commitment of all responsibility for assuring faithful law-execution to the President. As a simple matter of text-reading, it is difficult to believe that Article II's two references to "Departments" could mean different things when both appear in the same Article, separated by only a few lines. Functionally, one may observe that the President's right to demand an opinion in writing about its exercise of its duties is the only stated relationship he is given to any department, once the moment of appointment has passed. Thus, it appears to be an essential element of presidential oversight authority respecting the faithful execution of the laws by any body to which Congress has entrusted their administration.

The PCAOB's protection from removal from office except "for cause," as found by the $S E C$, was the single flaw the majority identified in the statute. It found that the "preservation of political accountability" - that is, preservation of the effectiveness of the President's constitutional position at the head of executive government-precluded this protection. The members of the SEC, it asserted, were themselves protected from removal from office except "for cause." To say that they were in charge of removing Board members, but themselves could do so only if stringent "for cause" provisions were satisfied - to permit Congress to create one "independent" authority within another-would be to allow the delegation of important executive "duties" to officials

52 Free Enter. Fund v. Pub. Co. Accounting Oversight Bd., 130 S. Ct. 3138, 3163 n.11 (2010). 
beyond the President's effective ability to oversee their conduct of office.

PCAOB authority could be preserved, the majority found, because this statutory flaw could be cured by severing the offensive "for cause" removal provisions from the statute. Once this had been done, the PCAOB's affirmative responsibilities and authority could persist unimpaired. It is simply that its members would now perform their functions under the same possibility of discipline as direct SEC employees face, leaving "the President separated from Board members by only a single level of good-cause tenure. The Commission is then fully responsible for the Board's actions, which are no less subject than the Commission's own actions to Presidential oversight." ${ }_{53}$ As that level of control over SEC staff was constitutionally sufficient to recognize the President's necessary authority to oversee the actions of the executive branch, it must be sufficient for the Board as well. While the majority said only that it had not been invited to reexamine Humphrey's Executor and was not doing so, the necessary implication of its finding of PCAOB constitutionality on this rationale is to reaffirm the result in Humphrey's Executor. In at least some settings, Congress can create elements of the executive branch whose heads are removable only "for cause." The constitutionality of the PCAOB's authority could not conscionably have been sustained without accepting the single level of "for cause" protection the majority attributed to the SEC.

How, then, could "opinion in writing" possibly be excluded? The majority opinion sustains the PCAOB's authority in every respect. An explicit element of this conclusion, again effectively unanimous, was that this authority was authority to execute the laws. Only on that basis could presidential oversight, on the need for which all agreed, be constitutionally required. That is, it was precisely the President's oversight authority respecting the SEC on which the majority opinion premised its acceptance of the PCAOB's affirmative powers, once it had eliminated the hurdle of the Members' removal "for cause" protection. While Chief Justice Roberts's opinion cites the ostensible "no part of the executive branch" theory of Humphrey's Executor, that theory too has now been abandoned. The independent regulatory commissions are seen as an element of government necessarily subject to presidential oversight, because they execute the laws. This recognition, too, is most welcome, but surely it carries with it such definition of presidential relationship to the Departments as the Constitution states.

Indeed, just because it is so accepting of a single level of "for cause" protection, the result will not satisfy those who take the strongest

53 Id. at 3161. 
view of presidential authority-that our President must be able to discipline any executive officer, and command his or her performance of discretionary duty along the lines that he prefers. For them, even a single level of "for cause" protection should be found impermissible. They had hoped that the Court would reach back to undo the mischief they believe had been done to that view when in Humphrey's Executor a unanimous Court permitted Congress to establish agencies whose heads could be removed only "for cause." 54 No Justice in $P C A O B$ suggested any sympathy for such a view. Strikingly, every reference in the majority opinion to the President's constitutional authority invoked his necessary prerogative to oversee, not to decide, the actions of executive departments.

The flaw in the argument of the strong presidentialists, to be brief about it, is that they stop reading Article II after its first sentence. But it goes on. While it describes the President as "Commander in Chief" of the military-no question here, he is entitled to issue orders that are to be unquestioningly obeyed, and violation may be treated as a military offense-all it says about his relationship to domestic authorities once appointed is that he is entitled to "require the Opinion, in writing, of the principal Officer in each of the executive Departments, upon any subject relating to the Duties of their respective Offices." This power, which as holder of "the executive power" it seems he must have over the SEC as well as the EPA, ${ }^{55}$ stands in sharp contrast to being "Commander in Chief." The agencies have the duties; he gets to reason with them, as he strives to "take Care that the Laws be faithfully executed." And for him to ignore those placements of "Duties" in others would in itself be to fail to "take Care that the Laws be faithfully executed." Again, the question is not whether he is entitled to command or decide, but what constitute the constitutionally indispensable elements of his necessary oversight relationship.

Despite the mildness of the outcome in the case, the theoretical explanation the majority offered for its conclusion seems to sweep more broadly than the particulars of the case require. Apparently deliberate ambiguities in the majority opinion leave for the future the task of reconciling the ostensible theory of its actions with the realities of common government arrangements. Justice Breyer's strident dissent for the (relatively) liberal wing of the Court (himself and Justices Ginsburg, Sotomayor, and Stevens) suggested two problems with the majority's "single level" limitation. First, it is not at all clear that it is violated by the "for cause" protection of PCAOB members; as we have seen, the SEC statute, quite deliberately at the time of its enactment, did not provide "for cause" protection to the members of the SEC. Second, if

\footnotetext{
54 Id.

55 But see supra text accompanying note 52 .
} 
one looks past the PCAOB to the enormous variety of statutory provisions respecting government employment, one easily finds hundreds if not thousands of government employees who can only be removed "for cause" by superiors who themselves can only be removed "for cause." The majority deals with the first problem by bold assertion, and with the second-reminiscent of the Freytag footnote that engendered the effective overruling of that case in this one ${ }^{56}$-by leaving such questions to another day.

The majority's handling of the first of these issues is quite astonishing, particularly coming from conservative Justices who repeatedly assert that it is for Congress, not the courts, to make lawthat the courts are obliged to take statutes as Congress has written them. Justice Breyer observed in his dissent that the SEC statute had been written after the decision in the Myers case (recall that the conventional reading of Myers was that it recognized as a matter of constitutional necessity an unfettered presidential right to remove executive officers ${ }^{57}$ ), but before Myers's qualification by Humphrey's Executor. ${ }^{58}$ Congress had enacted the FTC's "for cause" provision before Myers. Now it omitted a similar provision from the SEC statute, unwilling to take the risk that if that provision was found unconstitutional, the result would be to jeopardize the whole scheme. Perhaps its members understood that, in any event, presidential interference with such a commission would generate enough political heat to dissuade any President from dismissing a commissioner without an articulable, apolitical reason..$^{59}$ Would it be proper for a court to insert a protection of tenure that the legislature did not enact, even inadvertently?

The opinion in Myers suggested the possibility of limits to the President's removal power for officials serving as adjudicators-and this reservation has been picked up in subsequent cases. ${ }^{60}$ But the Myers opinion, the Court's general jurisprudence before and after it, and the ready implication of the President's constitutional duty to assure the faithful execution of the laws, all establish rather clearly that the default position is that the President may remove any Department head, and Department heads may remove any officers inferior to them, at will. It took a statute to create the civil service system; congressional practice is to specify those higher offices from which incumbents may be removed only "for cause." Since there is no such statute for the SEC Commissioners, even though custom and political realities doubtlessly

56 See supra text accompanying note 37 .

57 See supra text accompanying note 20.

58295 U.S. 602 (1935).

59 President Roosevelt had removed Commissioner Humphrey from his FTC office solely because their politics differed and he wanted a Commissioner more sympathetic to his views.

60 See, e.g., Wiener v. United States, 357 U.S. 349 (1958) 
support such a constraint, one would think that as a matter of law SEC commissioners serve at the President's pleasure. And, if so, the twolevel proposition on which the majority opinion turns is irrelevant, for only PCAOB Members, and not Commissioners, are protected from removal unless "for cause."

The majority's entire discussion of the point, in response to Justice Breyer's argument?

The parties agree that the Commissioners cannot themselves be removed by the President except under the Humphrey's Executor standard of "inefficiency, neglect of duty, or malfeasance in office." 295 U. S., at 620 (internal quotation marks omitted); see Brief for Petitioners 31; Brief for United States 43; Brief for Respondent Public Company Accounting Oversight Board 31 (hereinafter PCAOB Brief); Tr. of Oral Arg. 47, and we decide the case with that understanding. ${ }^{61}$

That is, the majority decided by bare assertion a question of law on which their holding that the PCAOB "for cause" removal provision was unconstitutional utterly depended-relying on party choices of how to argue the case. A brief filed amicus curiae, not mentioned by the majority, had informed the Court of the problem. The failure of any party to argue it, as Professor Richard Pierce has remarked, can be ascribed to self-interested motives of a kind that usually are taken as a signal of improper litigation about constitutionality.

The petitioners did not want to take the position that the SEC statute authorizes at will removal because that would undermine their argument about dual insulation from presidential control. The SEC did not want to take that position because it wanted to preserve the option of making an argument ... that the structure of the statute suggests a congressional intent to insulate the Commissioners from at will removal.... I have it on good authority that PCAOB wanted to make that argument but that SEC overruled it. That alone suggests that SEC could control PCAOB even before the majority eliminated the limits on the SEC's power to remove Board members. ${ }^{62}$

61 Free Enter. Fund v. Pub. Co. Accounting Oversight Bd., 130 S.Ct. 3138, 3148 (2010).

62 Posting of Richard Pierce to Adminlaw listserv (June 30, 2010) (on file with author). The larger problem, Professor Pierce remarked, is what any court should do when it becomes aware that the parties are colluding to further their own goals?... I think it is entirely appropriate for SEC to litigate that question, and it is possible that the Court would rely on dicta in Wiener and Humphrey's to hold that the President can only remove Commissioners for cause. What I find indefensible is the majority's reliance on the parties' collusive but dubious "understanding" that SEC Commissioners can be removed only for cause as the foundation for its holding that the removal provision applicable to PCAOB is unconstitutional.

Id. One could add that for the Court's conservative wing to be doing this is especially remarkable. 
As Professor William Funk remarked in the same informal internet forum, "[t]o decide the constitutionality of a statutory provision based upon an 'understanding' agreed to by the parties as to the meaning of another relevant statutory provision ... is, I believe, as unique as the PCAOB itself." 63

If one turns to the merits of the two-level proposition, one can find a certain tension in the majority opinion, one element of which forcefully animates Justice Breyer's dissent. At places, the majority appears to be objecting to Congress's creation of a "for cause"-protected institution (the PCAOB) within another "for cause"-protected institution (the SEC). In this respect, the PCAOB is, to the author's knowledge, virtually unique. The other such institutions of which the author is aware-for example the Atomic Safety and Licensing Appeals Board of the Nuclear Regulatory Commission-have only adjudicatory responsibilities. While their actions are nominally to be regarded as executive actions, because they occur in an element of the executive branch in which they reside, nonetheless these "quasi-adjudicatory" actions fall within the reservation noted in Myers and drawn on in later cases, ${ }^{64}$ that presidential oversight of adjudicatory functions is properly limited in the interest of their quasi-judicial character and attendant considerations of fairness. The PCAOB, on the other hand, is not a committed adjudicator. It has the same full range of responsibilities government agencies commonly possess-rulemaking and enforcement in addition to adjudication. For an entity operating over that full range, the argument for presidential oversight is considerably stronger.

Had the majority clearly held only that Congress could not constitutionally create one fully-functioned, "for cause"-protected agency within another such agency, there would have been little to write about. It is hard to imagine such a conclusion doing much mischief. ${ }^{65}$ In some of its discussion, the majority embraces such a limitation, viz.:

The only issue in this case is whether Congress may deprive the President of adequate control over the Board, which is the regulator of first resort and the primary law enforcement authority for a vital sector of our economy. We hold that it cannot. ${ }^{66}$

Yet in other passages, the majority's reasoning appears to be about the removability vel non of individual PCAOB members as "inferior officers," evoking the Edmonds test. For example, Chief Justice Roberts' opinion asserts:

63 Posting of William Funk to Adminlaw listserv (June 30, 2010) (on file with author).

64 See supra note 59.

65 Here, however, the author must confess to not knowing enough about the structures, powers, and interrelationships of the Federal Reserve and its constituent Federal Reserve banks to say whether they might be threatened even by so limited a proposition.

66 Free Enter. Fund, 130 S. Ct. at 3161. 
[W]e have previously upheld limited restrictions on the President's removal power. In those cases, however, only one level of protected tenure separated the President from an officer exercising executive power. It was the President-or a subordinate he could remove at will-who decided whether the officer's conduct merited removal under the good-cause standard....

If Congress can shelter the bureaucracy behind two layers of goodcause tenure, why not a third? ${ }^{67}$

In responding to the dissent's elaboration of the thousands of government officials who meet Edmonds's "inferior officer" test, the majority does not say that it is dealing with the status of an institution, but rather responds as if those cases are to be resolved on other grounds, grounds consistent with a standard governing individual "officers" like each of the Board's members, rather than institutions like the PCAOB.

$[\mathrm{M}]$ any civil servants within independent agencies would not qualify as "Officers of the United States," who "exercis[e] significant authority pursuant to the laws of the United States," Buckley, 424 U.S. [1], at 126. $\left[{ }^{68}\right] \ldots$ We do not decide the status of other Government employees, nor do we decide whether "lesser functionaries subordinate to officers of the United States" must be subject to the same sort of control as those who exercise "significant authority pursuant to the laws." Buckley, supra, at 126, and n. 162.

Nor do the employees referenced by the dissent enjoy the same significant and unusual protections from Presidential oversight as members of the Board.... [M]embers of the Senior Executive Service may be reassigned or reviewed by agency heads.... Nothing in our opinion ... should be read to cast doubt on the use of what is colloquially known as the civil service system within independent agencies.

Finally, the dissent wanders far afield when it suggests that today's opinion might increase the President's authority to remove military officers.... The President and his subordinates may ... convene boards of inquiry or courts-martial to hear claims of misconduct or poor performance by those officers... Here, by contrast, the President has no authority to initiate a Board member's removal for cause. ${ }^{69}$

67 Id. at 3153-54.

68 The following text appears as footnote nine in the above-excerpted portion of Free Enterprise Fund v. Public Co. Accounting Oversight Board: "One 'may be an agent or employee working for the government and paid by it, as nine-tenths of the persons rendering service to the government undoubtedly are, without thereby becoming its office[r].' United States v. Germaine, 99 U.S. 508, 509 (1879) ... ." Id. at 3160 n.9.

$69 \mathrm{Id}$ at 3160-61 (footnotes and citations omitted) (quoting Buckley v. Valeo, 424 U.S. 1, 126 \& n.162 (1976)); id. at $3160 \mathrm{n} .9$ ("One "may be an agent or employee working for the government and paid by it, as nine-tenths of the persons rendering service to the government undoubtedly are, without thereby becoming its office[r]."' (citing United States v. Germaine, 99 U.S. 508, 509 (1879)); id. at $3160 \mathrm{n} .10$ ("For similar reasons, our holding also does not address 
Perhaps the reliance on Buckley is indeed a signal that the majority holding is limited to the heads of discrete institutions. That case involved an Appointments Clause challenge to the members of the Federal Election Commission, a freestanding body lacking any such relationship as the PCAOB has with the SEC. At the place in Buckley Chief Justice Roberts referenced one finds this text:

If "all persons who can be said to hold an office under the government about to be established under the Constitution were intended to be included within one or the other of these modes of appointment," United States v. Germaine, supra, it is difficult to see how the members of the Commission may escape inclusion. If a Postmaster first class, Myers v. United States, 272 U.S. 52 (1926), and the clerk of a district court, Ex parte Hennen, 13 Pet. 230 (1839), are inferior officers of the United States within the meaning of the Appointments Clause, as they are, surely the Commissioners before us are at the very least such "inferior Officers" within the meaning of that Clause. ${ }^{70}$

At the end of this passage one finds footnote 162:

"Officers of the United States" does not include all employees of the United States, but there is no claim made that the Commissioners are employees of the United States rather than officers. Employees are lesser functionaries subordinate to officers of the United States, see Auffmordt v. Hedden, 137 U.S. 310, 327 (1890); United States v. Germaine, supra, whereas the Commissioners, appointed for a statutory term, are not subject to the control or direction of any other executive, judicial, or legislative authority. (Emphasis added). ${ }^{71}$

Saying only that the FEC Commissioners were "at the very least ... 'inferior Officers" perhaps reflected a compromise needed to secure an opinion "for the Court" in Buckley; as it is, the majority opinion in that case stretches well over 100 pages in US Reports. Nonetheless, the failure to agree that Officers "not subject to the control or direction of any other executive, judicial, or legislative authority" are, indeed, principal officers who must be appointed with the Senate's advice and consent, is remarkable. One supposes, indeed, that, like the Commissioners of the SEC, FEC Commissioners must be appointed by the President with the advice and consent of the Senate and that their actions are executive actions, with the necessary continuing role of

that subset of independent agency employees who serve as administrative law judges. ... [U]nlike members of the Board, many administrative law judges of course perform adjudicative rather than enforcement or policymaking functions,... or possess purely recommendatory powers. The Government below refused to identify either 'civil service tenureprotected employees in independent agencies" or administrative law judges as "precedent for the PCAOB.” (citing 537 F.3d 667, 699, n.8 (D.C. Cir. 2008) (Kavanaugh, J., dissenting)).

70 Buckley v. Valeo, 424 U.S. 1, 126 (1976).

71 Id. at 126 n. 162. 
presidential oversight the $\mathrm{PCAOB}$ majority insists that conclusion entails.

As noted above, one of the petitioners' major arguments had been that the members of the PCAOB must be regarded as principal officers and, given the SEC's strong "control or direction" over their actions, that argument did not attract a single vote. ${ }^{72}$ Whatever may be the case for FEC Commissioners, the members of the PCAOB, fitting the Edmonds formula, are "inferior officers." On the other hand, they do head a discrete body with a full range of administrative responsibilities and a distinct legal personality. What is curious, then, is that the $P C A O B$ majority did not make explicit that this institutional character was an element of its reasoning, limiting its holding to the heads of discrete institutions. Rather, it seems to have indicated that it would treat the "inferior officer" question case by case.

This is what makes the Buckley signal ambiguous. If, as in Freytag, a minor quasi-judicial actor is an "officer of the United States," or if, as in Edmonds, a Coast Guard officer is, then the implications of denying the possibility of two-level "for cause" protection at the level of the individual rather than the institution are enormous, as Justice Breyer's dissent principally argues. The majority's failure to be explicit about this is regrettable; its promise to take the matter up case by case is what recalls the tensions created by the Freytag footnote.

Justice Breyer, exploiting this seemingly intentional irresolution in the majority opinion, details at length the variety of government officials who meet the Edmonds test. Persons appointed to leadership positions in independent agencies and removable by their agency head only "for cause" enjoy the same two levels of "for cause" protection as the members of the PCAOB. When the majority reasons that striking the "for cause" protection of $\mathrm{PCAOB}$ members renders them subject to the same level of presidential control as any inferior officer of the SEC, it elides the possibility that some of those inferior officers-for example, its Inspector General ${ }^{73}$ or its Administrative Law Judges-are themselves removable only "for cause," by an agency itself enjoying "for cause" protection. The members of the Nuclear Regulatory Commission and the Commissioner of the Social Security Administration are protected by "for cause" removal restrictions; and, as Justice Breyer details, so are a great many of the officials who head their various bureaus and subdivisions. It might suffice to say-but this is what the majority surprisingly did not say-that those bureaus and subdivisions are merely parts of the larger agency, lacking the full range of administrative powers or a separate legal personality. But it does not suffice to say that if they are members of the Senior Executive Service 
(SES), they "may be reassigned or reviewed by agency heads." Not all of them are members of the SES-the NRC's chief officers, for example - and all of them do have quite a significant level of authority, easily meeting the Edmonds test. ${ }^{74}$ Nor is the power of reassignment and review in the SES the equivalent of removal.

The uncertainties seemingly cultivated by the majority opinion illustrate once again just how hard it is to accommodate the governmental structures Congress has created for the twenty-first century to a Constitution created in the eighteenth. Freytag had seemed to doom independent agencies' powers of appointment with its impeccable originalist reasoning about the necessity strictly to limit the dispersal of appointment powers to a handful of cabinet-level bodies. After Freytag, thinking back to my time as General Counsel of the Nuclear Regulatory Commission, appointed by the Commission, I had to wonder if my commission had been legally valid. With one hand the PCAOB majority has lifted that shadow-what is a "Department" whose head(s) must be appointed by the President with the advice and consent of the Senate (and who may then themselves be vested with the power to appoint inferior officers) cannot be limited in the way Freytag seemed to say. But the NRC General Counsel's office is one that appears in Justice Breyer's extensive appendices; the General Counsel is not a member of the Senior Executive Service; and his authorities to represent the Commission, to write and file its briefs, etc., clearly mark him as an "inferior officer." With its other hand, then, the majority may have said that the NRC's General Counsel-or the SEC's Inspector General--may not serve under the protection of "for cause" removal. As in Freytag, only the promise of decision case-by-case in the futurenot the sort of promise one would ordinarily expect to be acceptable to the conservative side of the Court's bench ${ }^{75}$ - preserves the possibility of that protection's survival.

The underlying issue, as both opinions recognize, is finding a way of accommodating the prolixity of government structures Congress creates without teaching Congress how to avoid the President's constitutionally necessary role as our unitary executive. If Congress, knowing it cannot itself appoint to executive office, could find the means to vest that power in a person or body that was itself independent of presidential oversight, that line would have been crossed. On the one hand, it seems the PCAOB is such a body; on the other, it does not.

74 Historically, before the creation of the SES, bureaucrats with remarkable levels of authority - the heads of the Forest Service and of the Social Security Administration-were civil servants, under the protections of the civil service system. See HERBERT KAUFMAN, THE ADMINISTRATIVE BEHAVIOR OF FEDERAL BUREAU CHIEFS (1983).

75 Cf. United States v. Mead Corp., 533 U.S. 218, 239 (2001) (Scalia, J., dissenting). 


\section{CONCLUSION}

In the end, the majority's solution in $P C A O B$ appears to have avoided large disruptions to the institutions whose responsibilities were immediately before them, rescuing every element of the PCAOB's authority save the formal tenure protection of its members. Treating the SEC Commissioners as protected from removal save "for cause," however surprising for Justices usually disposed to leave the writing of laws to Congress, is itself a beneficial step. One would have to look long and hard to find developed systems anywhere in the world that deliver financial institutions into politicians' direct control. Control of the markets and of the money supply is not safe in their hands. This is a judgment Congress made as early as the first Bank of the United States and continued with the Federal Reserve. The Constitution does not require otherwise and the Court avoided the least suggestion otherwise.

As to the general question of what the Constitution provides about the relationship between President and the Departments of executive government, in some respects matters are more settled than they had been at the beginning of the year. Looking at the propositions on which all nine Justices agree, one can see the independent regulatory commissions now clearly placed where they should be - not a "headless fourth branch," but elements of the executive branch in a different-but necessary-oversight relationship with the President. The Supreme Court's most important function, as Charles Black once remarked, lies in its legitimation of Congress's choices, not the opposite. If a marginal element of congressional choice fails the test, that has far less significance than a judgment pulling the string on an extraordinary range of long-established institutions.

But of just what does that necessary relationship consist? Between the majority's strange refusal to say, flat out, that its conclusion entailed a presidential right to demand "opinions in writing" from the SEC ${ }^{76}$ and the ambiguities of its two-level formulation, much remains unresolved.

76 See, e.g., Free Enter. Fund v. Pub. Co. Accounting Oversight Bd., 130 S. Ct. 3138, 3163 n.11 (2010). 